\title{
Isolation of an Inducible Amidase from Pseudomonas acidovorans AE1
}

\author{
By JEANETTE ALT AND K. KRISCH \\ Biochemisches Institut im Fachbereich Medizin der Universität Kiel, Kiel 23, Germany \\ AND P. HIRSCH \\ Institut für Allgemeine Mikrobiologie der Universität Kiel
}

(Received 9 September 1974)

\begin{abstract}
SUMMARY
A bacterial strain, AEI, which hydrolysed acetanilide, was isolated from soil and identified as Pseudomonas acidovorans. Numerous amides, esters and enzyme inhibitors were tested as amidase inducers. Phenacetin was chosen as inducer for the large scale cultivation of these organisms because it was less toxic to the bacteria than acetanilide. The induction increased the enzymic activity $250-$ fold. In comparison, the type culture strain of $P$. acidovorans, ATCCI 5668, had no amidase activity which could be induced by phenacetin. Optimal growth conditions were established with respect to the concentration of carbon source and inducer so that about $10 \%$ of the extractable bacterial protein consisted of the amidase. The organisms were lysed with lysozyme in the presence of EDTA and the enzyme was isolated mainly by column chromatography procedures. A preparation from $60 \mathrm{~g}$ (wet wt) bacteria yielded about $100 \mathrm{mg}$ highly purified amidase with a specific activity of $\mathrm{I} 37 \mu \mathrm{mol}$ substrate hydrolysed $/ \mathrm{min} / \mathrm{mg}$ protein. In addition to acetanilide, the purified enzyme hydrolysed several other amides and esters. As standard substrate, $p$-nitroacetanilide was chosen.
\end{abstract}

\section{INTRODUCTION}

During a search for acetanilide-hydroxylating mono-oxygenases in micro-organisms, a bacterial strain was isolated from soil which catalysed the hydrolysis of acetanilide ( $F$. Bernhardt, personal communication). An enzyme with the same activity had previously been isolated from pig liver microsomes (Krisch, I963a), and this proved to be identical to the well-known unspecific carboxylesterase (EC. 3.I.I.I) (Krisch, I963 b).

As part of a larger comparative project on the molecular and catalytic properties of esterases, it seemed worthwhile to include studies of a bacterial amidase/esterase.

We report the identification of the acetanilide-hydrolysing strain, its optimal growth conditions and large-scale cultivation. Results of induction studies and the isolation of the amidase to a homogeneous state are also described.

\section{METHODS}

Isolation of bacteria. The culture was obtained from F. Bernhardt (Giessen, Germany), who had previously isolated the strain from soil using a mineral salts medium (Ribbons \& Evans, 1962) which contained $0.4 \%(\mathrm{w} / \mathrm{v})$ acetanilide as sole carbon and energy source.

Growth of cultures. Cultures were maintained on agar slants prepared from Standard 
I-Nähragar (Merck, Darmstadt, Germany). Incubation was at $30{ }^{\circ} \mathrm{C}$; fully grown cultures were stored at $4{ }^{\circ} \mathrm{C}$. One litre of culture medium contained: I M-phosphate buffer $\mathrm{pH} 6.8$ (40 ml); 'Hutner's vitamin-free mineral base' (Cohen-Bazire, Sistrom \& Stanier, 1957) (20 $\mathrm{ml})$; and $10 \%(\mathrm{w} / \mathrm{v})\left(\mathrm{NH}_{4}\right)_{2} \mathrm{SO}_{4}$ solution ( $\left.\mathrm{IO} \mathrm{ml}\right)$. This comprised the 'standard mineral base' as described by Stanier, Palleroni \& Doudoroff (I966). Carbon source, inducer and yeast extract $(\mathrm{O} \cdot \mathrm{I} \mathrm{g} / \mathrm{l})$, were added to this solution except in the tests for utilization of single organic carbon and energy sources. The $\mathrm{pH}$ was adjusted to 6.8 before autoclaving, and was found to be between $7 \cdot 0$ and $7 \cdot 2$ afterwards.

Measurement of bacterial growth. As an indicator of growth yield, the extinction at 660 $\mathrm{nm}$ (I cm light path) was measured with a PM4 spectrophotometer (Carl Zeiss, Oberkochen, Germany). Viable counts were obtained from plate counts, and the total number of microorganisms was determined with a Thoma cell counting chamber. A total number of $1 \mathrm{I}^{8}$ bacteria $/ \mathrm{ml}$ gave an $E_{1 \mathrm{~cm}}$ of 0.094 . The relation was linear up to $E_{1 \mathrm{~cm}}=0.8$.

Identification of species. For genus determination Bergey's Manual of Determinative Bacteriology (1957) was used. Species identification was carried out according to Stanier et al. (1966).

Chemicals. D-Fucose, D-tryptophan and valine were purchased from Serva, Heidelberg, Germany, sodium maleate, geraniol and $\delta$-aminovalerate from Fluka, Eschborn, Germany, and $p$-hydroxybenzoate from Riedel de Haen, Seelze-Hannover, Germany; all other chemicals were from Merck.

Induction experiments. All substances to be tested as possible inducers were added at concentrations of $0.0 \mathrm{I}$ to $0.18 \%(\mathrm{w} / \mathrm{v})$ to a culture medium containing $0.55 \%(\mathrm{w} / \mathrm{v})$ lactic acid. The $\mathrm{pH}$ was adjusted to 6.8 with $6 \mathrm{M}-\mathrm{NaOH}$. The bacteria were grown for $72 \mathrm{~h}$ at $30{ }^{\circ} \mathrm{C}$ and then harvested by centrifuging ( $30 \mathrm{~min}, \mathrm{I} 2000 \mathrm{~g}$ ). Sediments were stored frozen before testing. The bacterial sediment was disintegrated by lysozyme (see Disruption of bacteria, below) and the supernatant liquid was kept refrigerated until the assays of activity and protein could be carried out.

The following substances were tested as inducers. Amides: acetanilide, acetamide, $p$ ethoxyacetanilide (phenacetin), sulphanilamide, nicotinamide, xylocaine, L-leucineamide, L-leucine- $\beta$-naphthylamide, L-tyrosyl-tyrosine, glycyl-L-proline, L-leucyl-glycine, glycyltyrosine, leucyl-tyrosine, phenylalanyl-phenylalanine, benzoyl-L-arginineamide, monoethylglycine-xylidide. Esters: $N$ - $\alpha$-benzoyl-L-arginine-ethylester, $N$-benzoyl-L-tyrosine-ethylester, acetyl-L-tyrosine-ethylester, L-tyrosine-ethylester, L-phenylalanine-methylester, diethylaminoethyl-diphenylpropyl-acetate (SKF 525-A). Other substances: aniline, $p$-aminobenzoic acid, $p$-hydroxybenzoic acid, naphthalene, $\beta$-naphthylamine, xylidine, $p$-ethoxyaniline (phenetidine), 2,6-dimethylaniline.

The phenacetin used for the induction was a product of Merck (No. 722I), and fulfilled the purity requirements of the British Pharmacopoeia 1968 and the Deutsche Arzneimittelbuch DAB 7. The melting point was 135.5 to $136{ }^{\circ} \mathrm{C}$ ( 137 to $138{ }^{\circ} \mathrm{C}$, Handbook of Chemistry and Physics, 1969-1970; $134.7^{\circ} \mathrm{C}$, D'Ans-Lax, 1964). A thin-layer chromatogram according to Bernhammer \& Krisch (I965) showed only one spot.

Growth of large bacterial quantities. The inoculum was pre-grown for $24 \mathrm{~h}$ in a mineral salts medium with $0.22 \%(\mathrm{w} / \mathrm{v})$ lactic acid without phenacetin. The $\mathrm{pH}$ was adjusted to $6 \cdot 8$ with $6 \mathrm{~m}-\mathrm{NaOH}$. The main batch culture was carried out in 51 flasks containing 41 of the same medium with I $g$ phenacetin/l. These flasks were inoculated with $200 \mathrm{ml}$ of the culture grown without phenacetin. After $72 \mathrm{~h}$ of vigorous aeration at $30^{\circ} \mathrm{C}$, the bacteria were harvested by continuous flow centrifuging (Sorvall KSB, I; Sorvall Inc., Norwalk, Connecticut, U.S.A.). The total yield was frozen at $-18{ }^{\circ} \mathrm{C}$. 
Disruption of bacteria. In preliminary experiments ultrasonic treatment with an $80 \mathrm{~W}$ sonifier Type B I2 (Branson Instruments, Inc., Stamford, Connecticut, U.S.A.) was used. The sonified solution was carefully cooled with ice water.

To obtain optimal conditions for lysis the EDTA concentration was varied. In such preliminary experiments the suspensions were incubated for $2 \mathrm{~h}$ at $30^{\circ} \mathrm{C}$. After centrifuging, the sediments were not washed. For standard enzyme preparations the bacteria were suspended in $4 \mathrm{ml} 0.05 \mathrm{M}$-phosphate buffer $\mathrm{pH} 7.5$ (containing $0.025 \mathrm{M}$-EDTA) per gram bacterial wet weight. Lysozyme ( $15000 \mathrm{u} / \mathrm{mg}$, Merck) was added to a concentration of $0.5 \mathrm{mg} /$ $\mathrm{ml}$. This mixture was then stirred for $\mathrm{I} 6 \mathrm{~h}$ at $4{ }^{\circ} \mathrm{C}$ and an extract obtained by centrifuging for $30 \mathrm{~min}$ at $100000 \mathrm{~g}$. The sediment was washed once with the same volume of distilled water. The $\mathrm{pH}$ was kept constant at $7 \cdot 5$. Distilled water for washing, instead of buffer, was necessary for the subsequent removal of nucleic acids. The supernatant liquid was combined with the extract and the resulting solution used for further enzyme purification.

Determination of amidase activity. The hydrolysis of $p$-nitroacetanilide was measured at $405 \mathrm{~nm}$ (I cm light path) in an Eppendorf photometer connected with an Eppendorf recorder (Netheler \& Hinz, Hamburg, Germany). The cuvette contained I ml substrate solution ( $\mathrm{IO}^{-3} \mathrm{M}$ - $p$-nitroacetanilide dissolved in warm water and then cooled to room temperature) and $\mathrm{I} \mathrm{ml} \mathrm{O} \mathrm{I} \mathrm{M}$-tris buffer $\mathrm{pH} 8.6$ containing the enzyme. The measurements were performed at $30{ }^{\circ} \mathrm{C}$. The molar extinction coefficient of $p$-nitroaniline in $0.05 \mathrm{M}$-tris buffer $\mathrm{pH}$ 8.6 was $100001 / \mathrm{mol} / \mathrm{cm}$.

Protein determination. The protein concentration was determined using a micro version of the biuret method (Beisenherz et al. 1953). Water and protein solution were combined in Eppendorf micro test tubes (Netheler \& Hinz) to a total volume of I $\mathrm{ml}$. Then $0.2 \mathrm{ml}$ of a $3 \mathrm{M}$-trichloroacetic acid solution was added. This mixture was shaken for $5 \mathrm{~min}$ with an Eppendorf rotation shaker. The denatured protein was then sedimented by centrifuging for I min in an Eppendorf microcentrifuge and the supernatant liquid discarded. The sediment was subsequently dissolved in $0.5 \mathrm{ml}$ biuret reagent and $0.5 \mathrm{ml}$ water and measured after $30 \mathrm{~min}$ in microcuvettes ( $2 \mathrm{~cm}$ path length) at $546 \mathrm{~nm}$, with bovine serum albumin as standard. After column chromatography, the fractions were measured at $280 \mathrm{~nm}(0.5 \mathrm{~cm}$ light path) for protein determination.

Enzyme isolation. Step I : Removal of nucleic acids. Streptomycin sulphate was added to the crude extract to a final concentration of $\mathrm{I} g / \mathrm{I} 00 \mathrm{ml}$. The sample was then centrifuged for $30 \mathrm{~min}$ at $12000 \mathrm{~g}$ and the precipitate discarded.

Step 2: Fractional precipitation by ammonium sulphate. To the supernatant liquid from step I, solid ammonium sulphate was slowly added until the solution was $30 \%$ saturated. The sulphate concentration was checked by titration with $\mathrm{BaCl}_{2}$ (Bergmeyer et al. $\left.196 \mathrm{I}\right)$. The reaction mixture was centrifuged for $30 \mathrm{~min}$ at $12000 \mathrm{~g}$, the sediment discarded, and further ammonium sulphate added to the supernatant liquid until $65 \%$ saturation was reached. During the precipitation the $\mathrm{pH}$ was kept constant at $7 \cdot 5$. After centrifuging for $30 \mathrm{~min}$ at $\mathrm{I} 2000 \mathrm{~g}$ the sediment was dissolved in $0.005 \mathrm{M}$-tris buffer $\mathrm{pH} 8.6$ containing $0.00 \mathrm{I}$ M-EDTA and $2 \%(\mathrm{v} / \mathrm{v})$ glycerol. This buffer will be designated as 'tris buffer for column chromatography'.

Step 3: Column chromatography with DEAE-Sephadex A-50. The enzyme solution was either dialysed or desalted by gel filtration on a Sephadex G-50 column (Pharmacia, Uppsala, Sweden) and applied to a DEAE-Sephadex A-50 column (Pharmacia; $5 \times 50 \mathrm{~cm}$ ). The DEAE-Sephadex was equilibrated with tris buffer for column chromatography. A gradient was applied from a 2-vessel gradient system. The first vessel contained I I00 $\mathrm{ml}$ tris buffer for column chromatography, and the second vessel contained the same buffer with $0.35 \mathrm{M}$ - 
$\mathrm{NaCl}$. The fractions containing amidase activity were combined and dialysed against tris buffer for column chromatography containing ammonium sulphate, the concentration of which had been calculated to yield a final concentration of $65 \%$ saturation after dialysis.

Step 4: Gel filtration. The enzyme precipitate was centrifuged and dissolved in as little phosphate buffer $(0.005 \mathrm{M}, \mathrm{pH} 8.0)$ as possible. This solution was applied to a column $(2.5 \times 100 \mathrm{~cm})$ filled with Sephadex G-IOO (Pharmacia) pretreated as specified by the manufacturer.

Step 5: Hydroxyapatite. Bio-Gel HTP (Bio-RAD Laboratories, Richmond, California, U.S.A.) was equilibrated with $0.005 \mathrm{M}$-phosphate buffer $\mathrm{pH} 8.0$. The pooled enzyme (after gel filtration) was applied to a hydroxyapatite column $(2 \cdot 5 \times \mathrm{I} 3 \mathrm{~cm})$. The adsorbed protein was eluted with a linear phosphate buffer gradient $\mathrm{pH} 8.0$ from 0.005 to $0.06 \mathrm{M}$. Temperature and rate of elution were kept constant (Bernardi, I97I). If necessary the rate of elution was restricted to $\mathrm{I} \mathrm{ml} / 3 \mathrm{~min}$.

Purity of the enzyme. Analytical disc electrophoresis. This was performed according to Hedrick \& Smith (I968) with 4,6 or $8 \%$ (w/v) polyacrylamide gels. The protein was stained with $1 \%$ amidoblack in $7 \%$ acetic acid and the gels were electrophoretically destained with $7 \%$ acetic acid. Staining of esterase activity with $\alpha$-naphthyl acetate was performed as described by Heymann, Junge \& Krisch (1972).

Reaction with diethyl $p$-nitrophenylphosphate. A $10^{-2} \mathrm{M}$ stock solution of diethyl-pnitrophenylphosphate (purity $>98 \%$; Bayer, Leverkusen, Germany) was prepared according to Krisch (1966). The absorbance difference was measured in microcuvettes (light path $2 \mathrm{~cm}$ ) at $405 \mathrm{~nm}$ with an Eppendorf photometer. The test tube contained $0.25 \mathrm{ml} 0.2 \mathrm{M}$-tris buffer $\mathrm{pH} 8.0,0.05 \mathrm{ml}$ diethyl-p-nitrophenylphosphate stock solution and $0.2 \mathrm{ml}$ of a highly purified enzyme solution (containing 0.5 to I $\mathrm{mg}$ protein $/ \mathrm{ml}$ ). The extinction of buffer, diethyl- $p$-nitrophenylphosphate and enzyme was subtracted from the 'initial burst'. The amount of $p$-nitrophenol was calculated using the extinction coefficient as determined by Krisch (I966): $\epsilon=\mathrm{I} 62401 / \mathrm{mol} / \mathrm{cm}$ at $\mathrm{pH} 8 \cdot 0$.

\section{RESULTS \\ Species identification}

A comparison of the isolate with Pseudomonas acidovorans ATCCI 5668 (kindly provided by Professor R. Y. Stanier) showed the same 'general characters of diagnostic value for the differentiation of species of aerobic pseudomonads' (Stanier et al. 1966). Our isolate and the reference strain differed in using phenacetin as the only source of carbon and energy. Strain ATCCI 5668 did not grow at all, while strain AEI grew after a period of about two weeks. From this plate a second strain, AE2, was isolated which had the same properties as strain AEI except that it grew spontaneously with phenacetin as single carbon and energy source. These observations were reproducible. Strain ATCCI5668 had no amidase activity which could be induced by phenacetin.

\section{Induction}

The average amidase activity (substrate: $p$-nitroacetanilide) of the crude extract from uninduced bacteria was $0.16 \mu \mathrm{mol} / \mathrm{min} / \mathrm{mg}$ (25 experiments). The extremes were 0.05 and $0.5 \mathrm{I} \mu \mathrm{mol} / \mathrm{min} / \mathrm{mg}$. Repeated measurements showed a large scattering of the values: the relative standard deviation was $75 \%$ of the mean. Phenacetin was the best inducer (Figs. I and 2 and Table I). In some tests acetamide, xylocaine, acetanilide and aniline showed an induction too (Tables I and 2), but the induction with phenacetin was more intensive and reproducible. 


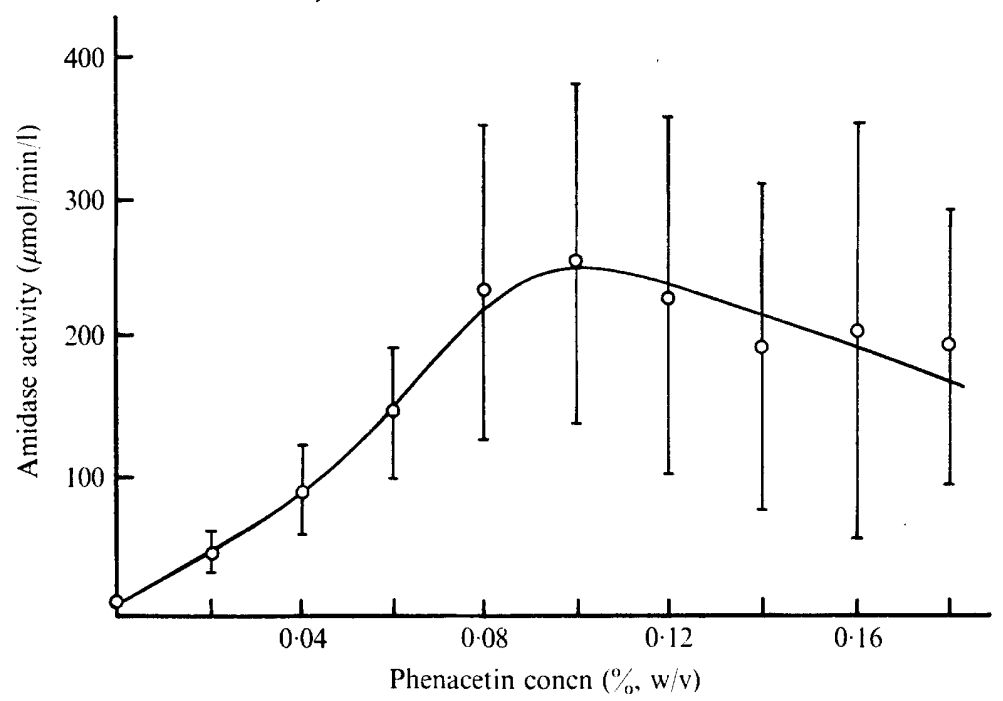

Fig. I. Total amidase activity as a function of the phenacetin concentration. Points indicate the mean values of 15 experiments, vertical bars represent the standard deviation.

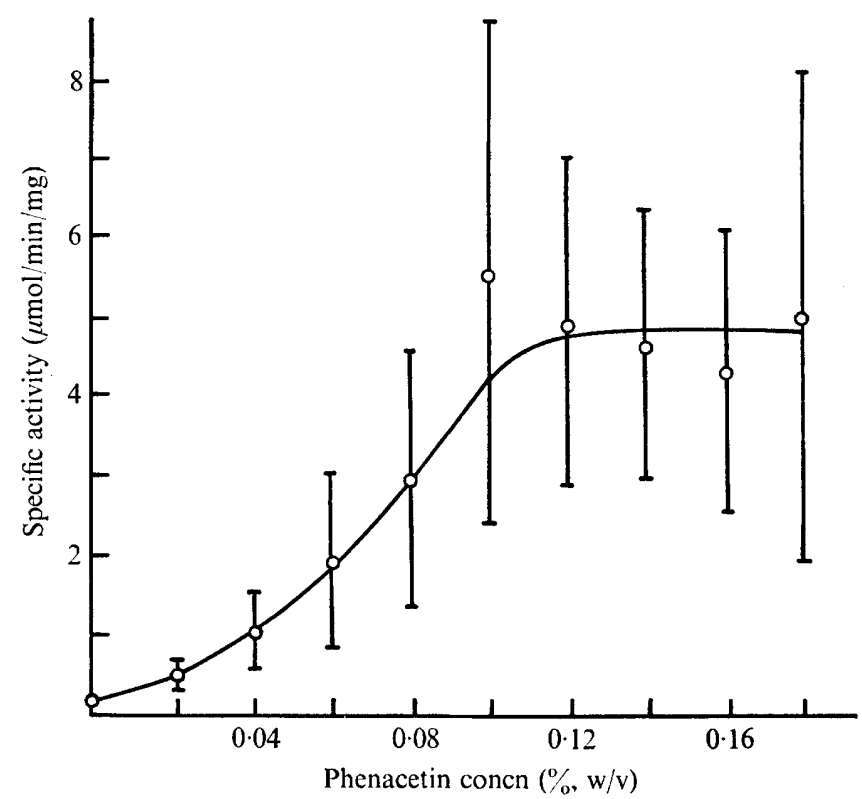

Fig. 2. Specific activity of the supernatant liquid from lysed bacteria as a function of the phenacetin concentration of the growth medium. Points indicate the mean values of 15 experiments, vertical bars represent the standard deviation.

\section{Growth of bacteria}

We tested $0.5 \%(\mathrm{w} / \mathrm{v})$ succinate, $p$-hydroxbenzoate, lactate and adipate as carbon sources. Growth was best with lactate or succinate, and lactate was therefore chosen as the standard carbon and energy source. The lactate concentration optimal for the induction was dependent on the phenacetin concentration, the highest activity being obtained with $0.22 \%$ lactate at a phenacetin concentration of $0 . \mathrm{I} \%$. Higher lactate concentrations increased growth but 
Table I. Induction of the amidase from P. acidovorans AEI

The values are the results of individual experiments. They represent the relative increase of the specific activity as compared with controls without the inducer. Twenty-five other compounds were also tested (see Methods) but none had a significant inducing effect.

\begin{tabular}{ccc} 
Concn of the inducer $(\%) \ldots$ & \multicolumn{1}{c}{ Increase in specific activity $(\mu \mathrm{mol} / \mathrm{min} / \mathrm{mg})$} \\
Acetanilide & $\mathrm{I} \cdot \mathrm{I} 6,2 \cdot 42,3 \cdot \mathrm{I} 9$ & 0.03 \\
Acetamide & $3 \cdot 88, \mathrm{I} \cdot 35$ & $\mathrm{I} \cdot 66, \mathrm{I} \cdot 47$ \\
Aniline & $\mathrm{I} \cdot 56, \mathrm{I} \cdot 78$ & $\mathrm{I} \cdot 49$ \\
Xylocaine & $2 \cdot 02, \mathrm{I} \cdot 07, \mathrm{I} \cdot 65$ & $\mathrm{I} \cdot \mathrm{I}$ \\
Phenacetin & $6 \cdot 63,7 \cdot 02,2 \cdot 62$ & $47 \cdot 2,34 \cdot 6$
\end{tabular}

Table 2. Effect of acetanilide concentration on amidase activity

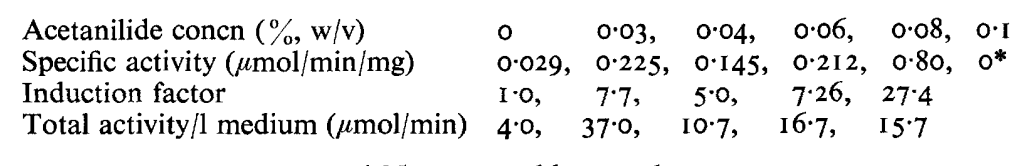

* No measurable growth.

\section{Table 3. Bacterial growth with different phenacetin concentrations}

The lactate concentration was $0.22 \%(\mathrm{w} / \mathrm{v})$. Bacteria were grown for $72 \mathrm{~h}$ at $30^{\circ} \mathrm{C}$.

$\begin{array}{ccc}\text { Phenacetin }(\mathrm{I} \% \text { w/v) } & \begin{array}{c}\mathrm{IO}^{-8} \times \text { Total counts } \\ \text { (bacteria/ml) }\end{array} & \begin{array}{c}\mathrm{IO}^{-8} \times \text { Viable counts } \\ (\text { bacteria } / \mathrm{ml})\end{array} \\ - & 20 & 10.5 \\ 0.02 & 19 & 9.8 \\ 0.06 & \mathrm{I} 5 & 7.8 \\ 0.10 & 6 & 5 . \mathrm{I} \\ 0.14 & 3 & 3.6\end{array}$

inhibited the induction, presumably due to 'catabolite repression' (Magasanik, I96I). Although higher concentrations of phenacetin inhibited bacterial growth (Table 3), induction of enzyme activity was enhanced even when some of the phenacetin remained undissolved after autoclaving. After $72 \mathrm{~h}$ growth, undissolved phenacetin could no longer be detected. The lag phase of the growth curve was prolonged by the addition of phenacetin. With $0.1 \%$ phenacetin the early exponential phase began after $20 \mathrm{~h}$. Maximal growth yield was then reached after about three days instead of one day.

\section{Disruption of bacteria}

The bacteria could successfully be disrupted by ultrasonic treatment. A high protein yield in the supernatant liquid could be reached after 4 min of sonication and was not much higher after $6 \mathrm{~min}$ of treatment. However, a serious disadvantage of this method was the destruction of enzymic activity. Bacterial disintegration with lysozyme in the presence of EDTA proved to be a better method for the conservation of enzyme activity. A concentration of $0.025 \mathrm{M}$-EDTA was found to be optimal for the yield of solubilized protein, and for activity and specific activity (Table 4). Some of the bacteria lysed with EDTA alone, i.e. in the absence of lysozyme, particularly if the bacteria had previously been frozen. The lysed bacteria were 
Table 4. Lysis of P. acidovorans AEI by lysozyme in the presence of different EDTA concentrations

After incubating with lysozyme for $2 \mathrm{~h}$ at $30^{\circ} \mathrm{C}$ the cultures were centrifuged for $30 \mathrm{~min}$ at $100000 \mathrm{~g}$. The protein concentration and amidase activity of the supernatant fluid were determined; the values are the results of two separate experiments.

\begin{tabular}{|c|c|c|c|c|c|c|}
\hline \multirow{3}{*}{$\begin{array}{l}\text { EDTA } \\
\text { concn } \\
(\mathrm{mol} / \mathrm{l})\end{array}$} & \multicolumn{2}{|c|}{$\begin{array}{c}\text { Protein } \\
\text { (mg/g bacteria) }\end{array}$} & \multicolumn{2}{|c|}{$\begin{array}{c}\text { Enzymic activity } \\
(\mu \mathrm{mol} / \mathrm{min} / \mathrm{g} \text { bacteria })\end{array}$} & \multicolumn{2}{|c|}{$\begin{array}{c}\text { Specific activity } \\
(\mu \mathrm{mol} / \mathrm{min} / \mathrm{mg} \text { protein })\end{array}$} \\
\hline & & -1 & & 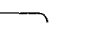 & & \\
\hline & $26 \cdot 8$ & 24.6 & 184 & I 54 & $6 \cdot 89$ & $6 \cdot 24$ \\
\hline 0.0063 & $38 \cdot 2$ & $37 \cdot 6$ & 184 & 194 & 4.83 & $5 \cdot 18$ \\
\hline 0.0125 & $35 \cdot 5$ & $3 I \cdot 5$ & 234 & 228 & $6 \cdot 55$ & $7 \cdot 23$ \\
\hline 0.025 & $46 \cdot 8$ & 43.0 & 607 & 650 & 13.0 & 15.2 \\
\hline 0.05 & $39 \cdot I$ & 38.5 & 391 & $48 I$ & 10.0 & 12.4 \\
\hline
\end{tabular}

Table 5. Purification of a p-nitroacetanilide hydrolysing enzyme from P. acidovorans AEI

This preparation was carried out with $63 \mathrm{~g}$ (wet wt) bacteria.

\begin{tabular}{|c|c|c|c|c|c|c|c|}
\hline Step & $\begin{array}{l}\text { Volume } \\
\text { (ml) }\end{array}$ & $\begin{array}{c}\text { Protein } \\
\text { concn } \\
(\mathrm{mg} / \mathrm{ml})\end{array}$ & $\begin{array}{l}\text { Total } \\
\text { protein } \\
(\mathrm{mg})\end{array}$ & $\begin{array}{c}\text { Specific } \\
\text { activity } \\
(\mu \mathrm{mol} / \mathrm{min} / \\
\mathrm{mg})\end{array}$ & $\begin{array}{l}\text { Total } \\
\text { activity } \\
(\mu \mathrm{mol} / \\
\text { min })\end{array}$ & $\begin{array}{l}\text { Purifica- } \\
\text { tion } \\
\text { factor }\end{array}$ & $\begin{array}{c}\text { Yield } \\
(\%)\end{array}$ \\
\hline $\begin{array}{l}\text { Crude extract (lysis + washing } \\
\text { of sediment) }\end{array}$ & 448 & $11 \cdot 3$ & 5060 & $10 \cdot 4$ & 52600 & I & 100 \\
\hline Addition of streptomycin & 463 & $9 \cdot 4$ & 4340 & II 15 & 50000 & $1 \cdot 2$ & 95 \\
\hline $\begin{array}{l}\text { fractionation } \\
\text { Desalting by gel filtration }\end{array}$ & $4 \mathrm{I}$ & 86 & $3530^{\circ}$ & $14 \cdot 3$ & 50500 & $1 \cdot 4$ & 96 \\
\hline (Sephadex G-5 & 236 & 15 & 3540 & 14.5 & 51 400 & $\mathrm{I} \cdot 4$ & $97 \cdot 7$ \\
\hline DEAE-Sephadex A-50 & 208 & $3 \cdot 3$ & 683 & 64 & 43700 & $6 \cdot 2$ & 83 \\
\hline Gel filtration (Sephadex G-100) & 70 & 5 & 350 & $88 \cdot 4$ & 30900 & $8 \cdot 5$ & $58 \cdot 7$ \\
\hline Hydroxyapatite & 116 & $\mathrm{I} \cdot \mathbf{2}$ & 134 & $131 \cdot 5$ & 17600 & $12 \cdot 7$ & $33 \cdot 4$ \\
\hline
\end{tabular}

extremely viscous, probably because of the liberation of high molecular weight nucleic acids. The viscosity disappeared after precipitation with streptomycin sulphate. A reproducible solubilization procedure was of particular importance for the induction experiments. The most reproducible method was lysis by lysozyme. If uninduced bacteria of one batch were divided into several portions and lysed, the standard deviation of the specific activity was only $\pm 6 \%$, the standard deviation of protein yield was $\pm 7 \%$, and of the total activity $\pm 6.5 \%$ of the respective average.

\section{Isolation of the enzyme}

Each preparation started from 50 to $70 \mathrm{~g}$ (wet wt) bacteria. An example of the purification procedure of the enzyme is given in Table 5 . The total purification is $12 \cdot 7$-fold and the yield $33 \%$. The purification was not very impressive because in the crude extract the enzyme is already the predominant protein. The individual purification steps may be summarized as follows:

Step $\mathrm{I}:$ lysis of the bacteria and solubilization of the enzyme. The lysed bacteria were highly viscous. To obtain a clear extract the preparation had to be centrifuged at $100000 \mathrm{~g}$ for $30 \mathrm{~min}$. On average, the supernatant contained $46 \pm 9 \cdot 3 \mathrm{mg}$ protein $/ \mathrm{g}$ lysed bacteria. The specific activity was $9 \cdot 3 \pm \mathrm{I} \cdot 7 \mu \mathrm{mol} / \mathrm{min} / \mathrm{mg}$ protein. The process of washing liberated an additional $25.5 \pm 6 \cdot 15 \mathrm{mg}$ protein/g bacteria with an average specific activity of $7 \cdot 0 \pm \mathrm{I} \cdot 8$ $\mu \mathrm{mol} / \mathrm{min} / \mathrm{mg}$. Altogether, more than $75 \%$ of the total activity was recovered in the super- 


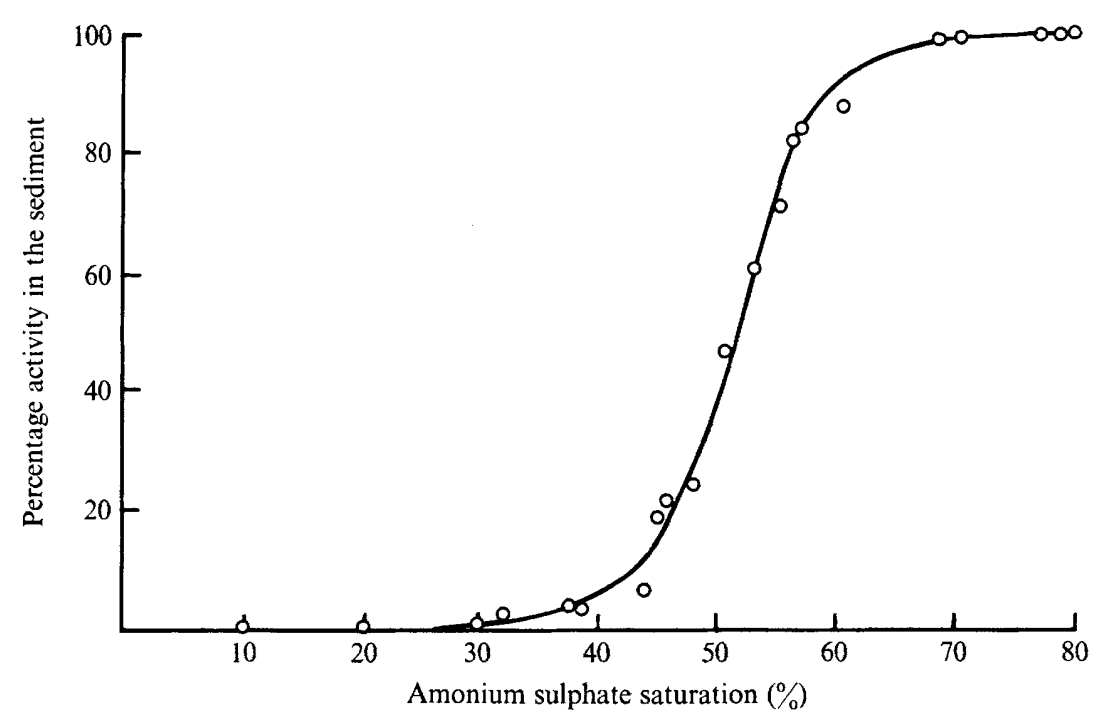

Fig. 3. Fractional precipitation by ammonium sulphate. The total activity before the addition of ammonium sulphate is taken as $100 \%$. Each point represents the mean of four experiments.

natant liquid (100\% activity was determined with the suspension of lysed bacteria before centrifugation). Intact bacteria had only half of the total activity.

Step 2: removal of nucleic acids. Relatively low phosphate and EDTA concentrations, e.g. $0.025 \mathrm{M}$-phosphate buffer with $0.00125 \mathrm{M}$-EDTA, were essential to precipitate nucleic acids by streptomycin. Otherwise the precipitate immediately redissolved and reappeared on dilution with distilled water. The sediment of lysed bacteria was therefore washed with distilled water instead of buffer. Before removal of nucleic acids the $E_{260}$ to $E_{280}$ ratio was about $\mathrm{I}: 4$; after streptomycin precipitation it had dropped to $\mathrm{I}: \mathrm{I}$.

Step 3: ammonium sulphate fractionation. Unlike the crude extract, the purified enzyme was rather susceptible to ammonium sulphate and could not be precipitated without considerable loss of activity. The fractional precipitation of the amidase by stepwise addition of $\left(\mathrm{NH}_{4}\right)_{2} \mathrm{SO}_{4}$ is shown in Fig. 3. Half of the total activity was precipitated at $52 \%$ ammonium sulphate saturation. For the enzyme isolation the fractionation of the protein was carried out in two steps, o to $30 \%$ saturation and 30 to $65 \%$ saturation. The sediment of the second step contained $90 \pm \mathrm{II} \%$ of the activity. However, the purification was $\mathrm{I} \cdot 3 \pm$ $0 \cdot I 2$-fold only. The specific activity after ammonium sulphate fractionation was II $\cdot 5 \pm 2 \cdot 5$ $\mu \mathrm{mol} / \mathrm{min} / \mathrm{mg}$.

\section{Separation by column chromatography}

Step 4: DEAE-Sephadex A-50. The enzyme was completely adsorbed to the gel. The enzyme was eluted at a $\mathrm{NaCl}$ concentration of $0.18 \pm 0.02 \mathrm{M}$ (Fig. 4). The purification was $4.4 \pm 0.4$-fold, and the specific activity after this step was about $60 \mu \mathrm{mol} / \mathrm{min} / \mathrm{mg}$.

Step 5: gel filtration. Of several gels tested the best separation was achieved with Sephadex G-IOO (Fig. 5). Moreover, by gel filtration the enzyme was desalted and therefore could immediately be applied to the hydroxapatite column. The purification was $\mathrm{I} \cdot 6 \pm 0 \cdot 2$-fold. This was in good agreement with the fact that about $50 \%$ of the applied protein mixture already consisted of the enzyme. The yield was unusually low in this step $(65 \pm 8.5 \%)$, probably because the enzyme became increasingly unstable with increasing purification. 


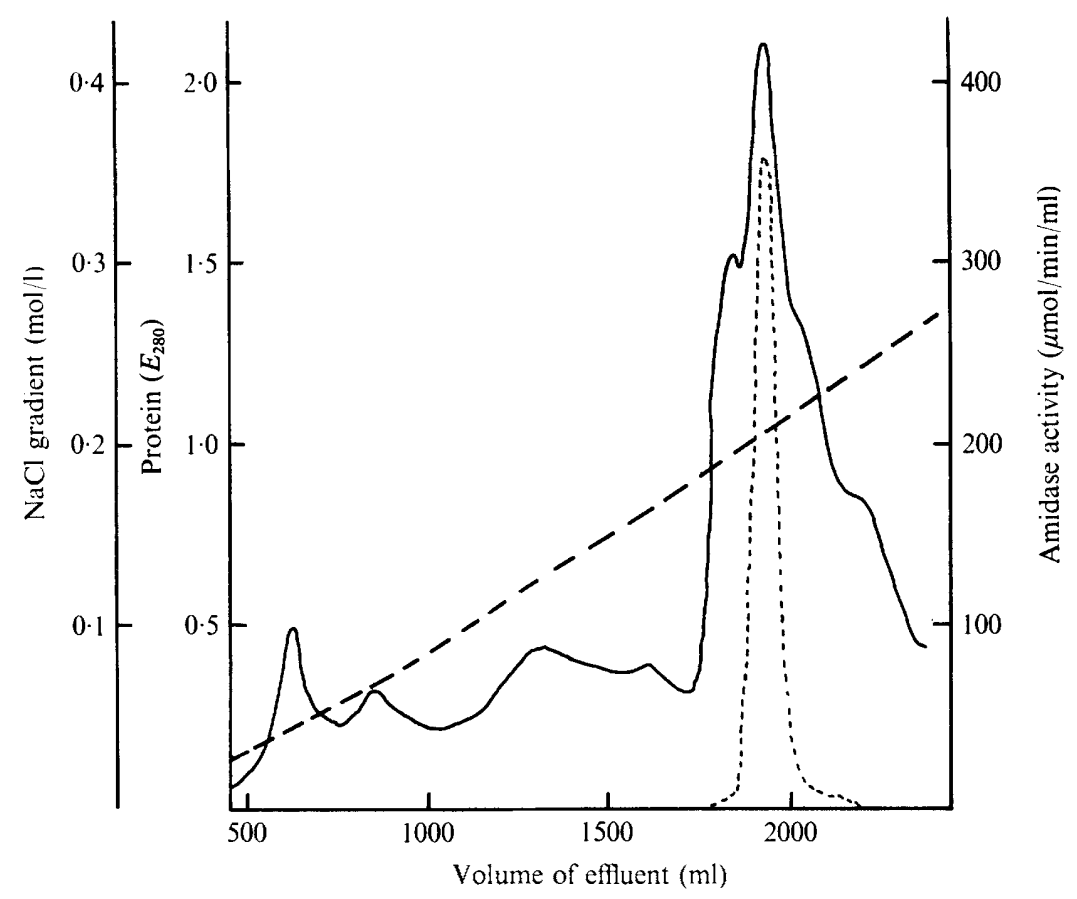

Fig. 4. Column chromatography of amidase on DEAE-Sephadex A-50. The protein was eluted with a linear gradient of from o to $0.35 \mathrm{M}-\mathrm{NaCl}$. The gradient was measured by flame photometry. —-, $E_{\varepsilon \text { so }}$; ----, gradient; -----, amidase activity.

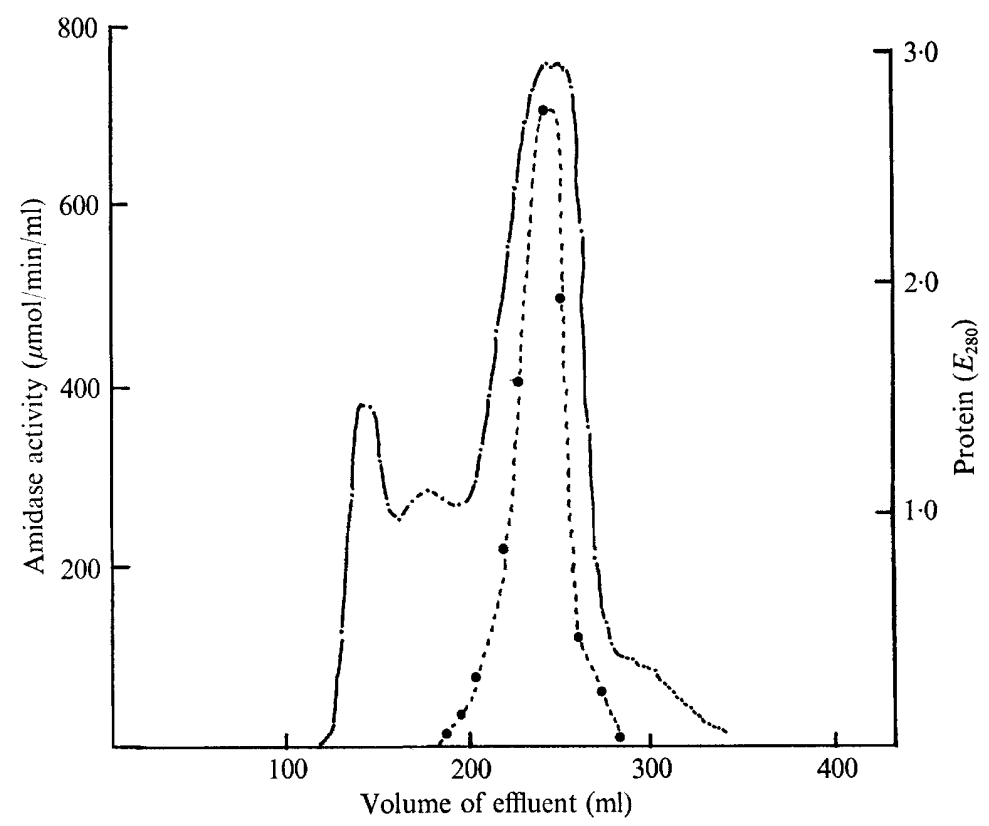

Fig. 5. Gel filtration of amidase on Sephadex G-IO0 (after chromatography on DEAE-Sephadex $\mathrm{A}-50)$.,$- E_{280} ;------$, amidase activity. 


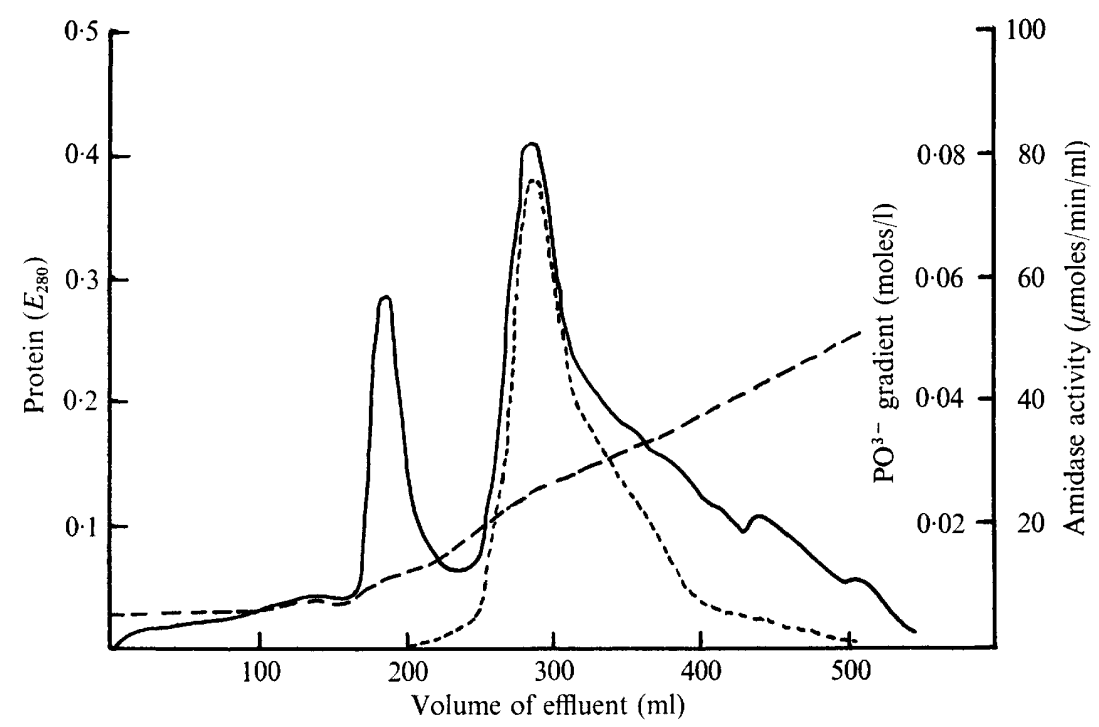

Fig. 6. Chromatography of amidase on hydroxyapatite. Gradient elution. The phosphate gradient was measured by conductometry. - -,$E_{280}$; ----, gradient; ---.--, amidase activity.

Step 6: adsorption chromatography with hydroxyapatite. Preliminary experiments showed that the enzyme, if dissolved in 0.005 M-phosphate buffer $\mathrm{pH} 8 \cdot 0$, was completely adsorbed to the hydroxyapatite. The elution, however, raised problems. Stepwise elution with phosphate buffer of increasing concentrations yielded one amidase peak with every elution step, whereas on gradient elution, only one peak trailing on the descending part (Fig. 6) or occasionally two peaks were obtained. Multiple enzyme peaks did not?necessarily indicate heterogeneity but were probably artefacts (Tiselius, Hjerten \& Levin, I956). To investigate this possibility further, enzyme-containing peaks from several experiments in which two peaks had been obtained were examined separately. After re-chromatography the elution pattern was the same for both peaks and corresponded to the pattern of the first chromatography. The enzyme from both peaks had the same molecular weight as determined by gel filtration. Analytical disc electrophoresis in $6 \%$ polyacrylamide gel revealed the same electrophoretic mobility for the amidase of either peak. In addition, both forms were inhibited by diethyl-p-nitrophenyl phosphate. These results indicate that the two forms were identical.

By chromatography on hydroxyapatite the final impurities could be removed, provided that specific activity before chromatography was $100 \mu \mathrm{mol} / \mathrm{min} / \mathrm{mg}$ or more. The average yield was $72 \%$ and the specific activity $\mathrm{I} 3 \mathrm{I} \pm 5.3 \mu \mathrm{mol} / \mathrm{min} / \mathrm{mg}$ (5 preparations). The chromatography with hydroxyapatite was reproducible only if all conditions, including temperature and velocity of elution, were kept constant.

\section{Stability of the enzyme}

In the presence of organic solvents and at $\mathrm{pH}$ values below 6.5 or above 9.5 , enzyme denaturation occurred rapidly. Precipitation of the enzyme by acetone, methanol or ethanol at temperatures below $0^{\circ} \mathrm{C}$ led to complete inactivation. The stability in tris buffer and phosphate buffer was the same. Glycerol $(2 \%, v / v)$ stabilized the enzyme, whereas a sample with $0.001 \mathrm{M}$-mercaptoethanol showed less stability. The presence of glycerol in tris buffer resulted in a $20 \%$ higher residual activity after 20 days. The stability of the enzyme decreased 


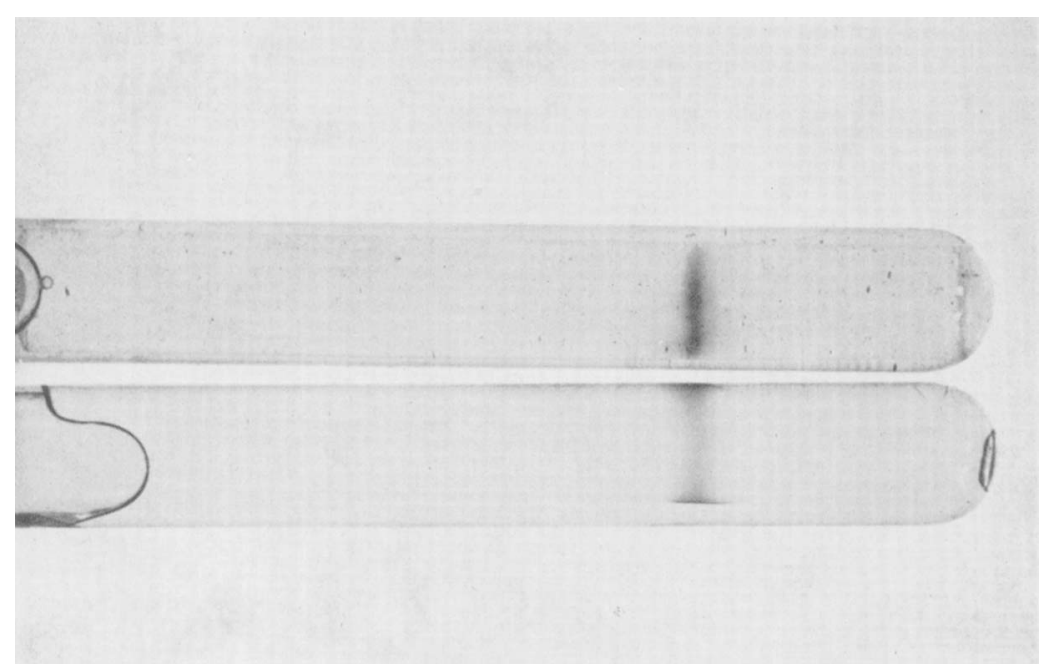

Fig. 7. Analytical disc electrophoresis of purified enzyme in $6 \%$ polyacrylamide gel according to Hedrick \& Smith (I968). Above: Amidoblack stain for proteins. Below: substrate stain ( $\alpha$-naphthyl acetate) for esterase activity.

with increasing purity and at higher dilutions. Chromatographic procedures performed with pure enzyme caused up to $90 \%$ loss of activity. After storing three months at $-18{ }^{\circ} \mathrm{C}, 77 \%$ of the activity of the highly purified enzyme was recovered.

\section{Criteria of purity}

Analytical disc electrophoresis. Disc electrophoresis of the crude extract from induced bacteria showed, among a variety of protein bands, one prevailing band which could be stained by $\alpha$-naphthylacetate. Enzyme preparations with a specific activity of $125 \mu \mathrm{mol} / \mathrm{min} /$ $\mathrm{mg}$ were homogeneous on disc electrophoresis (Fig. 7). The enzyme band had the same electrophoretic mobility as the main band of the crude extract and also reacted with $\alpha$-naphthylacetate.

Titration with diethyl-p-nitrophenyl phosphate. The enzyme was strongly inhibited by diethyl-p-nitrophenyl phosphate (Alt, Heymann \& Krisch, 1975). The highest specific activity, which was achieved in three out of eight preparations, was $137 \mu \mathrm{mol} / \mathrm{min} / \mathrm{mg}$. Only with these preparations was the equivalent weight identical with the molecular weight as determined by gel filtration and with the chain weight as determined by polyacrylamide gel electrophoresis in sodium dodecyl sulphate (Alt et al. 1975).

\section{DISCUSSION}

Enzymes hydrolysing amides of low molecular weight are quite common, not only in micro-organisms (Betz \& Clarke, I973; Kelly \& Clarke, I962; Myers, Tol \& DeJonge, I957; Draper, I967) but also in mammalian tissues. In many cases they are unspecific carboxylesterases (EC. 3.I.I . I), e.g. the esterase from pig liver which hydrolyses acetanilide as well as other aromatic amides and esters (for a review see Krisch, 197I). The mammalian enzymes are localized preferentially in the microsomal fraction, while the amidase of Pseudomonas acidovorans AEI presumably occurs in the cytoplasm or may be loosely bound to membranes. 
The high initial activity after induction, the fast growth of $P$. acidovorans AEI as well as the relatively convenient isolation procedure make this amidase a suitable object for a closer examination of its catalytic and molecular properties. The further characterization of the enzyme and its active site are reported elsewhere (Alt et al. 1975). Catabolite repression has also been observed with the acetamide hydrolysing amidase of Pseudomonas aeruginosa 8602/A (Brammar \& Clarke, 1964). However, with the enzyme of $P$. acidovorans AEI this cannot be overcome simply by adding more inducer, because phenacetin or a metabolite of it proved to be toxic for bacterial growth. For this reason it is important to keep the lactate concentration as low as possible.

The physiological function of mammalian esterases and amidases has not yet been elucidated. The liver esterase is probably important for the hydrolysis of certain drugs like acetanilide, phenacetin or procaine, and thus could contribute to the so-called detoxication of foreign compounds. The function of amidases or esterases in bacteria may be more easily explained. Most of them are inducible by substrates or analogous substances, for example, the enzymes of Mycobacterium smegmatis (D1aper, 1967) and of P. aeruginosa (Kelly \& Clarke, 1962; Betz \& Clarke, 1973). It can be assumed that these inducible enzymes are functioning in the dissimilation of carbon and nitrogen sources.

The aliphatic amidase from $P$. aeruginosa, which preferentially hydrolyses short-chain aliphatic amides, has been extensively studied by Clarke and her collaborators. Recently, mutants grown on acetanilide as sole carbon source were isolated. They produced amidases with different substrate specificities and electrophoretic properties from the parent strain (Brown \& Clarke, 1972). In another comparative study the biochemical and immunological properties of amidases from various Pseudomonas species were investigated. The amidases in extracts of cultures of acetamide-grown $P$. acidovorans strains 14 and NCIB968I showed strong cross-reactivity with an antiserum against $P$. aeruginosa A amidase (Clarke, 1972). They are possibly identical with the acetamide splitting activity found by us in crude extracts from $P$. acidovorans AEI. This activity, however, was lost during the purification procedure and the highly purified enzyme does not hydrolyse acetamide (Alt et al. 1975).

This work forms part of a doctoral thesis submitted by J.A. to the Kiel University. The culture of P.acidovorans was kindly provided by Dr F. Bernhardt. His advice was gratefully accepted.

\section{REFERENCES}

Alt, J., Heymann, E. \& Krisch, K. (1975). Characterization of an inducible amidase from Pseudomonas acidovorans. European Journal of Biochemistry (in the Press).

Beisenherz, G., Boltze, H. H., Bücher, T., Czok, R., Garbade, K. H., Meyer-Arendt, E. \& Pfleiderer, G. (1953). Diphosphofructose-Aldolase, Phosphoglyceraldehyd-Dehydrogenase, GlycerophosphatDehydrogenase und Pyruvat-Kinase aus Kaninchenmuskulatur in einem Arbeitsgang. Zeitschrift für Naturforschung 8b, 555-577.

Bergey's Manual of Determinative Bacteriology, 7 th edn (1957). Edited by R. S. Breed, E. G. D. Murray and N. R. Smith. London: Baillière, Tindall and Cox.

Bergmeyer, H.-U., Holz, G., Kauder, E. M., Möllering, H. \& Wieland, O. (196i). Kristallisierte Glycerokinase aus Candida mycoderma. Biochemische Zeitschrift 333, 47I-480.

Bernardi, G. (I971). Chromatography of proteins on hydroxyapatite. In Methods in Enzymology, vol. 22, pp. 325-339. New York and London: Academic Press.

Bernhammer, E. \& KRISCH, K. (I965). Deacetylation of phenacetin by liver esterase. Biochemical Pharmacology $14,863-87$ I.

BetZ, J. L. \& Clarke, P. H. (1973). Growth of Pseudomonas species on phenylacetamide. Journal of General Microbiology 75, 167-177.

Brammar, W. J. \& Clarke, P. H. (1964). Induction and repression of Pseudomonas aeruginosa amidase. Journal of General Microbiology 37, 307-319. 
Brown, P. R. \& Clarke, P. H. (1972). Amino acid substitution in an amidase produced by an acetanilideutilizing mutant of Pseudomonas aeruginosa. Journal of General Microbiology 70, 287-298.

Clarke, P. H. (1972). Biochemical and immunological comparison of aliphatic amidases produced by Pseudomonas species. Journal of General Microbiology 7I, 24I-257.

Cohen-Bazire, G. W., Sistrom, R. \& Stanier, R. Y. (1957). Kinetic studies of pigment synthesis by nonsulfur purple bacteria. Journal of Cellular and Comparative Physiology 49, 25-36.

DRAPER, P. (1967). The aliphatic acylamide amidohydrolase of Mycobacterium smegmatis: its inducible nature and relation to acyl-transfer to hydroxylamine. Journal of General Microbiology 46, I I I-I 23.

D’Ans-Lax (1964). Taschenbuch für Chemiker und Physiker. 2. Band: Organische Verbindungen. Edited by E. Lax. Berlin, Göttingen and Heidelberg: Springer Verlag.

Handbook of Chemistry and Physics (1969-I970), 50th edn. Ohio: Chemical Rubber Co.

Hedrick, J. L. \& Smith, A. J. (I968). Size and charge isomer separation and estimation of molecular weights of proteins by disc gel electrophoresis. Archives of Biochemistry and Biophysics 126, I55-164.

Heymann, E., Junge, W. \& Krisch, K. (1972). Carboxylesterase aus Schweinelebermikrosomen, Reaktion mit Phenylmethansulfonylfluorid und Nachweis von Isoenzymen. Hoppe-Seyler's Zeitschrift für Physiologische Chemie 353, 576-588.

Kelly, M. \& Clarke, P. H. (I962). An inducible amidase produced by a strain of Pseudomonas aeruginosa. Journal of General Microbiology 27, 305-316.

KRISCH, K. (1963a). Isolierung einer Esterase aus Schweinelebermikrosomen. Biochemische Zeitschrift 337, 53I-545.

KRISCH, K. (1963b). Eigenschaften und Substratspezifität einer Esterase aus Schweinelebermikrosomen. Biochemische Zeitschrift 337, 546-573.

KRISCH, K. (I966). Reaction of a microsomal esterase from hog-liver with diethyl-p-nitrophenyl-phosphate. Biochimica et biophysica acta I22, 265-280.

KRISCH, K. (I97I). Carboxylic ester hydrolases. In The Enzymes, vol. 5, pp. 43-69. Edited by P. D. Boyer. New York and London: Academic Press.

MaGaSanik, B. (196I). Catabolite repression. Cold Spring Harbor Symposia on Quantitative Biology 26, $249-256$.

Myers, D. K., Tol, J. W. \& DEJonge, M. H. T. (I957). Substrate specificity of the esterases of some saprophytic mycobacteria. Biochemical Journal 65, 223-232.

Ribbons, D. W. \& Evans, W. C. (1962). Oxidative metabolism of protocatechuic acid by certain soil Pseudomonads: a new ring-fission mechanism. Biochemical Journal 83, 482-492.

Stanier, R. Y., Palleroni, N. J. \& Doudoroff, M. (1966). The aerobic Pseudomonads: a taxonomic study. Journal of General Microbiology 43, I59-27I.

Tiselius, A., HJerten, S. \& Levin, Ö. (1956). Protein chromatography on calcium phosphate columns. Archives of Biochemistry and Biophysics 65, 132-155. 